\title{
Penentuan Penerimaan Usulan Penelitian Internal Dosen Menggunakan Metode Profile Matching
}

\author{
Vivi Sahfitri \\ Program Studi Manajemen Informatika \\ Universitas Bina Darma \\ Palembang, Indonesia \\ Email: vivi_sahfitri@binadarma.ac.id
}

\begin{abstract}
A Lecturer as an educator in Higher Education System has an obligation to fulfill the Tri Dharma University which consists of Education, Research and Community Service. A research, which is a part of the lecturer responsibility, shall be conducted in various activities with the cost coming from a wide range of sources. Bina Darma University through the Research and Community Service Institute has an agenda to administer Internal Research Grants which aim to facilitate and motivate Lecturers in the research activities. The assessment of Research proposal is carried out by a reviewer appointed directly by the institution. The reviewer has a full right to determine whether the proposal would be funded or not. The reviewer's full right may affect the objectivity of assessment by the Reviewer which eventually would influence the final decision. Thus, this research aims to design a system for determining the acceptance of Internal Research proposals, that is by using the implementation of Profile Matching Method. The final result of the study shows that the final value of the research proposal which will get the first rank is the value of the ID PROPO07 with the final value 4.55. Meanwhile, the lowest end value is 3.1 obtained by ID PROP004. The assessments criteria contained in the research proposal include abstract, introduction, literature review, research methodology, budget conformance and research schedule.
\end{abstract}

Keywords- Internal Research, Profile Matching Method, Assessment, Decision Support System

Abstrak - Dosen sebagai Tenaga Pendidik yang ada pada system pendidikan tinggi, memiliki kewajiban untuk memenuhi Tri Dharma Perguruan Tinggi yang terdiri dari Pendidikan, Penelitian dan Pengabdian Pada Masyarakat. Penelitian yang merupakan bagian dari Kewajiban yang harus dilaksanakan oleh seorang dosen dilaksanakan melalui berbagai kegiatan dengan biaya dari berbagai sumber. Universitas Bina Darma melalui Lembaga Penelitian dan Pengabdian pada Masyarakat (LPPM) memiliki agenda untuk menyelenggarakan Hibah Penelitan Internal yang bertujuan untuk memfasilitasi dan memotivasi dosen dalam kegiatan penelitian. Penilaian Usulan penelitian dilakukan oleh reviewer yang ditunjuk langsung oleh lembaga. Seorang reviewer memiliki hak penuh untuk memutuskan usulan proposal yang didanai dan yang tidak didanai. Hak penuh yang dimiliki reviewer akan mempengaruhi objektifitas penilaian oleh reviewer sehingga akan mempengaruhi keputusan yang akan diambil. Penelitan ini bertujuan untuk merancang sistem penentuan penerimaan usulan Penelitian Internal dengan mengimplementasikan Metode Profile Matching. Hasil akhir penelitian menunjukan nilai akhir usulan proposal yang paling tinggi akan memperoleh ranking pertama yaitu nilai pada ID PROP007 dengan nilai akhir 4,55. Sedangkan Nilai akhir terendah adalah 3,1 yang didapat oleh ID PROP004. Penilaian yang dilakukan meliputi kriteria- kriteria yang terdapat dalam usulan Penelitian yang meliputi Abstrak, Pendahuluan, Tinjauan Pustaka, Metodologi Penelitian, Kesesuaian Anggaran dan Jadwal Penelitian.

Kata Kunci- Penelitian Internal, Metode Profile Matching, Penilaian, Sistem Pendukung Keputusan.

\section{PENDAHULUAN}

Dosen adalah pendidik profesional dan ilmuwan dengan tugas utama mentransformasikan, mengembangkan, dan menyebarluaskan ilmu pengetahuan, teknologi, dan seni melalui pendidikan, penelitian, dan pengabdian kepada masyarakat. Penilaian kinerja dosen seharusnya mencakup kinerja dosen di bidang pendidikan, penelitian, dan pengabdian kepada masyarakat [1]. Kedudukan dosen sebagai tenaga professional memiliki fungsi untuk meningkatkan martabat dan peran dosen sebagai agen pembelajaran, pengembang ilmu pengetahuan, teknologi dan seni serta pengabdi kepada masyarakat berfungsi untuk meningkatkan mutu pendidikan nasional [2]. Perguruan tinggi adalah satuan pendidikan yang menyelenggarakan Pendidikan Tinggi [3]. Perguruan tinggi harus dapat menjamin penilaian kinerja dosen sebagai upaya meningkatkan kualitas dosen dan kualitas manajemen secara keseluruhan di Perguruan Tinggi [4]. Evaluasi kinerja dosen merupakan tantangan serius bagi pengelola perguruan tinggi [5]. Perguruan tinggi berkewajiban menyelenggarakan penelitian dan pengabdian kepada masyarakat disamping tugas pokoknya melaksanakan pendidikan.

Setiap Perguruan Tinggi diharapkan dapat mengelola penelitian di institusinya dengan memenuhi berbagai standar yang berkaitan dengan pelaksanaan kegiatan penelitian. Kegiatan penelitian memiliki peranan penting pada Perguruan Tinggi, bahkan beberapa negara, misal Australia, Selandia Baru, Inggris mengakui penelitian lebih penting daripada pembelajaran, dan pengabdian pada masyarakat [6]. Karena pada dasarnya Pilar Utama dalam Pendidikan tinggi adalah unsur Pembelajaran dan Unsur Penelitian [7]. Banyak faktor yang dapat menjadi motivasi atau pendorong bagi dosen untuk 
meningkatkan kualitas dan kuantitas penelitian yang dilakukan, antara lain; 1) tersedianya alokasi dana untuk pelaksanaan penelitian, 2) adanya penambahan fasilitas publikasi jurnal, 3) adanya insentif sebagai bentuk penghargaan, 4) keaktifan dosen dalam melaksanakan penelitian, serta 5) keaktifan dosen dalam kegiatan forum ilmiah [8].

Universitas Bina Darma merupakan salah satu Perguruan Tinggi Swasta yang berada di Kota Palembang. Untuk membantu dosen memenuhi kewajiban dalam kegiatan Tri Dharma Perguruan Tinggi terutama dalam Pelaksanan Kegiatan penelitian, Universitas Bina Darma melalui Lembaga Penelitian dan Pengabdian Kepada Masyarakar (LPPM) menyelenggarakan kegiatan Penelitian Internal bagi dosesn tetap dengan system pengelolaan, penilaian, pelaksanaan dan pendanaan yang dilakukan secara professional dan proporsional melalui tahapan yang diatur dalam panduan hibah penelitian internal yang sudah ada.

Penentuan penerima dana penelitian internal diawali dengan penilaian proposal yang dalam penentuan penilaian dan penentuan kelulusan proposal ditentukan sepenuhnya oleh reviewer yang ditunjuk oleh LPPM berdasarkan kriteria yang sudah ditentukan sebelumnya. Permasalahan yang menjadi perhatian dalam proses penilaian usulan penelitian adalah hak penuh yang dimiliki oleh reviewer yang ditunjuk untuk memberikan penilaian terhadap usulan penelitian. Penilaian yang hanya didasarkan dengan persepsi dan pandangan dari reviewer akan mempengaruhi Objektifitas penilaian Proposal yang akan dinilainya dan akan mempengaruhi keputusan yang akan diambil terkait dengan penerimaan usulan penelitian yang akan didanai Perguruan Tinggi.

Penelitian ini bertujuan untuk menganalisis penggunaan metode profile Matching untuk menentukan kelayakan proposal penelitian internal yang diterima. Profile Matching adalah metode yang sering digunakan sebagai mekanisme dalam pengambilan keputusan dengan mengasumsikan bahwa terdapat tingkat variable Predictor yang ideal yang harus dipenuhi oleh subjek yang diteliti, bukannya tingkat minimal yang harus dipenuhi atau dilewati [9].

\section{METODOLOGI PENELITIAN}

Pemecahan permasalahan yang ditemui dalam suatu penelitian harus dilakukan secara terstruktur dan sistematis, sehingga dalam pelaksanaannya dibutuhkan suatu metode tertentu agar pemecahan masalah lebih mudah untuk dilakukan. Metode penelitian merupakan cara ilmiah mendapatkan data yang valid dengan tujuan dapat ditemukan, dibuktikan, dan dikembangkan suatu pengetahuan sehingga pada gilirannya dapat digunakan untuk memahami, memecahkan, dan mengantisipasi masalah [10].

\section{A. Metode Penelitian}

Penelitian ini merupakan penelitian Kuantitatif dengan tipe deskriptif. Penelitian kuantitatif adalah penelitian yang menggunakan proses data-data yang berupa angka sebagai alat menganalisis dan melakukan kajian penelitian, terutama mengenai apa yang sudah di teliti [11]. Sedangkan penelitian deskriptif adalah metode penelitian yang digunakan untuk menemukan pengetahuan yang seluas luasnya terhadap objek penelitian pada suatu masa tertentu [12]. Sehingga dapat disimpulkan bahwa Penelitian Kuantitatif dengan tipe deskriptif adalah penelitian yang menggunakan data yang diperoleh dari sampel populasi dan kemudian dianalisis sesuai dengan metode statistic yang digunakan.

\section{B. Metode Profile Matching.}

Profile Matching merupakan metode kuantitatif yang digunakan dalam penelitian ini. Profile Matcing adalah metode yang sering digunakan sebagi mekanisme dalam pengambilan keputusan [9]. Profile matching secara garis besar adalah proses membandingkan antara nilai data aktual dari semua profil yang akan dinilai dengan profil yang diharapkan, sehingga akan diperoleh gap atau perbedaan. Pada Metode profile Matching semakin kecil gap yang diperoleh maka semakin besar bobot nilainya. Dalam Penelitian ini, proses profile matching yang dilakukan adalah pada proses membandingkan antara setiap kriteria penilaian dalam sebuah usulan proposal penelitian sehingga pada akhirnya akan diketahui perbedaan skor (gap) dari setiap usulan proposal tersebut. Semakin kecil gap yang dihasilkan maka akan semakin besar bobot nilainya, yang artinya peluang usulan proposal tersebut untuk diterima semakin besar pula.

Dalam penelitian ini analisis kebutuhan input adalah usulan penelitian yang sudah memenuhi syarat usulan penelitian terutama dari format dan sistematika usulan penelitian. Usulan penelitian yang dianggap telah memenuhi syarat penulisan akan diproses lebih lanjut untuk memperoleh keputusan pendanaan berdasarkan kriteria kriteria yang telah ditetapkan, meliputi; 1) Abstrak, 2) Pendahuluan, 3) Tinjauan Pustaka, 4) Metode Penelitian dan 5) Anggaran dan Jadwa Penelitian.

Berdasarkan kriteria-kriteria tersebut, selanjutnya akan dilakukan tahapan penilaian berdasarkan metode profile matching yaitu ; a) Pembobotan nilai pada setiap kriteria, b) Pembobotan nilai GAP, c)Perhitungan core factor, d) Perhitungan secondary factor, e) Perhitungan nilai total, f) Penentuan rangking

Dalam perhitungan untuk mengambil keputusan dengan menggunakan metode profile matching, tahapan yang dilakukan adalah sebagai berikut:

1) Pembobotan, yaitu penentuan bobot nilai masing-masing aspek yang digunakan dalam perhitungan.

Pembobotan dilakukan dengan menggunakan persamaan 1 . 
$G A P=$ Profil Proposal - Profil Ideal ..(1)

Sedangkan pembobotan nilai GAP pada masing masing kriteria [9] ditentukan berdasarkan tabel I.

TABEL I. BOBOT NILAI GAP

\begin{tabular}{|c|c|c|c|}
\hline No & Selisih & Bobot & Keterangan \\
\hline 1 & 0 & 5 & Tidak ada Selisih Kriteria \\
\hline 2 & 1 & 4,5 & Kriteria Kelebihan 1 level \\
\hline 3 & -1 & 4 & Kriteria kekurangan 1 level \\
\hline 4 & 2 & 3,5 & Kriteria kelebihan 2 level \\
\hline 5 & -2 & 3 & Kriteria kekurangan 2 level \\
\hline 6 & 3 & 2,5 & Kriteria kelebihan 3 level \\
\hline 7 & -3 & 2 & Kriteria kekurangan 3 level \\
\hline
\end{tabular}

Sumber : Kusrini (2007)

2) Pengelompokan core dan Secondary Factor; core factor merupakan kriteria penilaian utama dalam kaitannya dengan penelitian ini adalah kriteria utama yang harus terkandung dalam usulan proposal. Sedangkan secondary factor adalah kriteria pendukung selain kriteria yang ada pada core factor. Untuk menghitung Core factor dari sub kriteria digunakan persamaan (2) berikut.

$$
N C F=\frac{\sum N C(\text { Kriteria })}{\sum I C}
$$

keterangan :

NCF : Nilai Rata-rata core Factor

NC : Jumlah Total Nilai Core Factor

IC : Jumlah Item Core Factor

Sedangkan untuk menghitung secondary factor dari sub kriteria digunakan persamaan (3) berikut.

$$
N S F=\frac{\sum N S(\text { Kriteria })}{\sum I S}
$$

keterangan :

NSF : Nilai Rata-rata Secondary Factor

NS : Jumlah Total Nilai Secondary Factor

IS : Jumlah Item Secondary Factor

Nilai total dari kriteria akan diperoleh dari perhitungan dengan menggunakan persamaan (4). Penggunaan persentase adalah $60 \%$ Core Factor (CF) dan $40 \%$ Secondary factor $(S F)$.

$$
\left(\text { Total }_{\text {Kriteria }}\right)=(x) \% N C F+(x) \% N S F .
$$

3) Perhitungan Nilai Total, yaitu nilai yang diperoleh dari perhitungan core factor dan secondary factor. Berdasarkan nilai total akan diperoleh hasil Perangkingan, yaitu menentukan rangking atau urutan dari penilaian untuk mengetahui status diterima atau tidaknya usulan proposal tersebut. Perhitungan ranking menggunakan persamaan 5.

Ranking $=(x) \% N 1+(x) \% N 2+(x) \% N n$.
Keterangan :

$\mathrm{N} 1, \mathrm{~N} 2, \mathrm{Nn}$

(x)\%

: Nilai total per Kriteria

: Persentase nilai Kriteria

\section{Penelitian Terdahulu}

Penelitian yang berkaitan dengan Sistem Pendukung Keputusan sudah banyak dilakukan oleh peneliti sebelumnya. Berbagai metode yang diterapkan dalam membangun Sistem Pendukung Keputusan yang bertujuan untuk memudahan dalam mengambil keputusan dengan jumlah data yang banyak. Penelitian yang berjudul Sistem Pendukung Keputusan Seleksi Penerimaan Pegawai baru Menggunakan Metode profile matching pada kecamatan Silo [13], bertujuan untuk memperoleh pegawai yang berkualitas dengan penilaian secara objektif menggunakan metode profile matching. Penelitian ini juga melakukan perbandingan peringkat skor calon pegawai dengan cara manual dan denan menggunakan system untuk mengatahui perbedaaan hasil penilaian.

Penelitian lainnya yang berjudul Perbandingan Metode Profile Matching Dan Simple Additive Weighting Pada Penentuan Jurusan Siswa Kelas X SMA N 2 Ngaglik [14], dengan tujuan untuk mengetahui tingkat keberhasilan penerapan metode pada penentuan jurusan dengan menggunakan data dan kriteria yang sama. Hasil penelitian menunjukan Kedua metode yang digunakan dan melalui perhitungan dapat menunjukkan hasil akhir yang sama dan diperoleh berdasarkan kriteria dan data yang sama pula.

Referensi penelitian lain berjudul Pemilihan Penerima Beasiswa menggunakan metode profile Matching [15], bertujuan untuk memperoleh hasil pehitungan yang akurat dan tepat untuk memutusakan penerima beasiswa pada SMK AdDa'wah Jakarta. Hasil penelitian memberikan kesimpulan bahwa analisis data yang dilakukan menggunakan metode profile matching menunjukkan kemudahan dalam menentukan penerima beasiswa, sehingga penerapan metode profile matching dalam membangun sistem pendukung keputusan sangatlah tepat.

Penelitian yang dilakukan oleh Veti Apriani dengan judul Penerapan Profile Matching untuk Menentukan Pemberian Beasiswa pada Sekolah Menengah Atas [16] dengan tujuan untuk menentukan pemberian beasiswa kepada siswa Sekolah Menengah Atas yang dapat dijadikan sebagai salah satu pendukung keputusan para pemberi beasiswa dalam menentukan siswa yang berhak mendapatkan beasiswa. Penelitian ini memberikan kesimpulan bahwa metode profile matching dapat diimplementasi dalam sebuah sistem pendukung keputusan untuk mementukan pemberian beasiswa pada siswa Sekolah Menengah Atas.

Penelitian berjudul Penggunaan Metode Profile Matching Untuk Sistem Penunjang Keputusan Kenaikan Jabatan pada Instansi Pemerintah [17] yang bertujuan membangun sistem pendukung keputusan yang dapat membantu instansi terkait dengan memberikan rekomendasi dan pertimbangan untuk pengambilan keputusan dalam menentukan pegawai yang 
akan diberi kenaikan pangkat nantinya yang akan diberi jabatan.

\section{HASIL DAN PEMBAHASAN}

\section{A. Menentukan Kriteria dan bobot kriteria yang digunakan} dalam Profile Matching

Dalam penentuan penerimaan Usulan Penelitian Internal Dosen, perlu di tetapkan kriteria-kriteria dan pembobotannya yang akan digunakan sebagai dasar dalam menerima Usulan Proposal penelitian Internal Dosen. Kriteria-kriteria tersebut ditunjukkan pada tabel II.

TABEL II. PEMBOBotAN KRITERIA

\begin{tabular}{|l|l|c|}
\hline No & \multicolumn{1}{|c|}{ Kriteria } & Bobot (\%) \\
\hline 1 & Abstrak (BA) & 15 \\
\hline 2 & Pendahuluan (BP) & 25 \\
\hline 3 & Tinjauan Pustaka (BT) & 20 \\
\hline 4 & Metode penelitian(BM) & 25 \\
\hline 5 & Anggaran dan Jadwal Penelitian (BAJ) & 15 \\
\hline \multicolumn{2}{|c|}{ Total } & 100 \\
\hline
\end{tabular}

Sumber : Hasil Pengolahan data

Pembobotan kriteria pada tabel II menunjukkan bahwa setiap kriteria memiliki bobot persentase yang berbeda, dengan nilai persentase tertinggi adalah $25 \%$ yang ada pada kriteria Pendahuluan dan metode penelitian. Sedangkan nilai terendah adalah $15 \%$ pada kriteria Abstrak dan Kriteria Anggaran dan Jadwal Penelitian dan satu kriteria yang berbobot 20\% yaitu kriteria Tinjauan Pustaka.

\section{B. Menentukan Nilai Kriteria dan Sub Kriteria.}

Setelah mengetahui kriteria dan pembobotannya, maka perlu ditentukan nilai kriteria ataupun nilai sub kriteria. Nilai ini akan digunakan untuk melakukan perhitungan GAP nya. Tabel III menunjukkan penilaian kriteria Abstrak dengan bobot penilaian $15 \%$. Penilaian yang diberikan berupa skor dengan skala ordinal yaitu 1 bernilai kurang, 2 bernilai cukup, 3 bernilai baik dan 4 bernilai sangat baik dengan nilai range yang telah ditentukan

TABEL III. PENILAIAN KRITERIA ABStraK (BA)

\begin{tabular}{|l|c|c|}
\hline \multicolumn{1}{|c|}{ Nilai } & Range & Skor \\
\hline Sangat Baik & $>39-50$ & 4 \\
\hline Baik & $>26-39$ & 3 \\
\hline Cukup & $>13-26$ & 2 \\
\hline Kurang & $0-13$ & 1 \\
\hline
\end{tabular}

Sumber : Hasil Pengolahan data

Kriteria pendahuluan dibagi menjadi beberapa sub kriteria, hal ini dikarenakan pada bagian pendahuluan dalam suatu proposal terbagi menjadi beberapa sub bab yang menjelaskan hal-hal yang berkaitan dengan proposal yang diajukan. Sub kriteria dari kriteria Pendahuluan terbagi menjadi core factor yang terdiri dari Latar Belakang Masalah, Rumusan Masalah, dan Tujuan Penelitian dan Secondary Factor yang terdiri dari Manfaat Penelitian dan luaran yang dihasilkan.
Tabel IV, V dan VI menunjukan Penilaian Sub kriteria pada kriteria Pendahuluan yang menjadi Core Factor dalam penilaian Usulan Proposal Penelitian.

TABel iv. Penilaian Sub Kriteria Latar BelaKang

\begin{tabular}{|l|c|c|}
\hline \multicolumn{1}{|c|}{ Nilai } & Range & Skor \\
\hline Jelas & $>10-15$ & 3 \\
\hline Cukup Jelas & $>5-10$ & 2 \\
\hline Kurang Jelas & $>0-5$ & 1 \\
\hline
\end{tabular}

Sumber : Hasil Pengolahan data

TABEL V. PENILAIAN SUB KRITERIA RUMUSAN MASALAH

\begin{tabular}{|l|c|c|}
\hline \multicolumn{1}{|c|}{ Nilai } & Range & Skor \\
\hline Jelas & $>10-15$ & 3 \\
\hline Cukup Jelas & $>5-10$ & 2 \\
\hline Kurang Jelas & $>0-5$ & 1 \\
\hline
\end{tabular}

Sumber : Hasil Pengolahan data

TABel Vi. Penilaian Sub Kriteria TuJuan PEnelitian

\begin{tabular}{|l|c|c|}
\hline \multicolumn{1}{|c|}{ Nilai } & Range & Skor \\
\hline Jelas & $>10-15$ & 3 \\
\hline Cukup Jelas & $>5-10$ & 2 \\
\hline Kurang Jelas & $>0-5$ & 1 \\
\hline
\end{tabular}

Sumber : Hasil Pengolahan data

Penilaian Sub kriteria Latar Belakang, Rumusan Masalah dan Tujuan Penelitian dibagi menjadi 3 katagori skor penilaian untuk menilai kejelasan dari isi sub kriteria tersebut dalam proposal penelitian dengan skor 1 jika kurang jelas, 2 jika cukup jelas dan 3 jika latar belakang sudah jelas.

Tabel VII dan VIII merupakan penilaian sub kriteria Pendahuluan untuk sub kriterian Secondary Factor yang terdiri dari subkriteria Manfaat Penelitian dan Sub kriteria Luaran yang dihasilkan.

TABel ViI. Penilaian Sub Kriteria ManfaAt Penelitian

\begin{tabular}{|l|c|c|}
\hline \multicolumn{1}{|c|}{ Nilai } & Range & Skor \\
\hline Jelas & $>10-15$ & 3 \\
\hline Cukup Jelas & $>5-10$ & 2 \\
\hline Kurang Jelas & $>0-5$ & 1 \\
\hline
\end{tabular}

Sumber : Hasil Pengolahan data

TABel ViII. Penilaian Sub Kriteria LUaran Penelitian

\begin{tabular}{|l|c|c|}
\hline \multicolumn{1}{|c|}{ Nilai } & Range & Skor \\
\hline Jelas & $>10-15$ & 3 \\
\hline Cukup Jelas & $>5-10$ & 2 \\
\hline Kurang Jelas & $>0-5$ & 1 \\
\hline
\end{tabular}

Sumber : Hasil Pengolahan data

Skor penilaian yang diberikan pada Subkriteria manfaat penelitian dan Luaran Penelitian ini terbagi atas 3 katagori penilaian yaitu 1 jika kurang jelas, 2 jika cukup jelas dan 3 jika jelas. 
Tabel iX. Penilaian Kriteria Tinjauan Pustaka (BT)

\begin{tabular}{|l|c|c|}
\hline \multicolumn{1}{|c|}{ Nilai } & Range & Skor \\
\hline Lengkap dan Terbaru & $>75-100$ & 4 \\
\hline Lengkap & $>50-75$ & 3 \\
\hline Cukup Lengkap & $>25-50$ & 2 \\
\hline Kurang Lengkap & $0-25$ & 1 \\
\hline
\end{tabular}

Tabel X. Penilaian Kriteria MEtode Penelitian (BM)

\begin{tabular}{|l|c|c|}
\hline \multicolumn{1}{|c|}{ Nilai } & Range & Skor \\
\hline Lengkap dan Jelas & $>75-100$ & 4 \\
\hline Jelas & $>50-75$ & 3 \\
\hline Cukup Jelas & $>25-50$ & 2 \\
\hline Kurang Jelas & $0-25$ & 1 \\
\hline
\end{tabular}

Sumber : Hasil Pengolahan data

TABEl Xi. Penilaian Kriteria Anggaran dan Jadwal Penelitian (BAJ)

\begin{tabular}{|c|c|c|}
\hline Nilai & Range & Skor \\
\hline Realistis & $>75-100$ & 4 \\
\hline Cukup Realistis & $>50-75$ & 3 \\
\hline Kurang Realisitis & $>25-50$ & 2 \\
\hline Tidak Realistis & -25 & 1 \\
\hline
\end{tabular}

Tabel IX, X dan XI merupakan bobot penilaian untuk kriteria Tinjauan Pustaka, Metode penelitian serta Anggaran dan jadwal Penelitian. Skor yang diberikan untuk menilai kriteria ini terdiri dari; skor 1 untuk usulan yang tidak realistis, 2 untuk usulan yang kurang realistis, 3 untuk usulan yang cukup realistis dan skor 4 untuk usulan yang realistis.

\section{Perhitungan GAP dan Menentukan Pembobotan Kriteria.}

Untuk menghitung nilai GAP pada masing-masing kriteria dengan menggunakan persamaan (1) sehingga akan diperoleh bobot masing-masing kriteria berdasarkan tabel I.

TABEL XII. NILAI GAP DAN BOBOT ABSTRAK (BA)

\begin{tabular}{|c|c|c|c|}
\hline No & Proposal ID & SKOR & $\begin{array}{c}\text { Nilai } \\
\text { Proposal }\end{array}$ \\
\hline \multicolumn{3}{|c|}{ Nilai Proposal } & \\
\hline 1 & PROP001 & 2 & \\
\hline 2 & PROP002 & 4 & \\
\hline 3 & PROP003 & 3 & \\
\hline 4 & PROP004 & 1 & \\
\hline 5 & PROP005 & 2 & \\
\hline 6 & PROP006 & 3 & \\
\hline 7 & PROP007 & 4 & \\
\hline 8 & PROP008 & 2 & \\
\hline & Profil Ideal & 4 & \\
\hline \multicolumn{3}{|c|}{ Nilai GAP } & Bobot \\
\hline 1 & PROP001 & -2 & 3 \\
\hline 2 & PROP002 & 0 & 5 \\
\hline 3 & PROP003 & -1 & 4 \\
\hline 4 & PROP004 & -3 & 2 \\
\hline 5 & PROP005 & -2 & 3 \\
\hline 6 & PROP006 & -1 & 4 \\
\hline 7 & PROP007 & 0 & 5 \\
\hline 8 & PROP008 & -2 & 3 \\
\hline
\end{tabular}

Sumber : Hasil Pengolahan data
Tabel XII menunjukkan skor penilaian kriteria abstrak pada 8 usulan proposal. Berdasarkan profil ideal yang diperoleh dari skor penilaian kriteria abstrak tersebut dapat ditentukan nilai GAP dan Bobot dari masing masing proposal

Pada pembobotaan Pendahuluan, dibagi menjadi subkriteria yaitu core factor dan secondary Factor. Sebagai subkriteria core factor adalah latar belakang, Rumusan Masalah dan tujuan penelitian. Sedangkan sebagai subkriteria secondary factor adalah manfaat penelitian dan luaran penelitian. Nilai GAP dan Bobot pada Pendahuluan (BP) disajikan pada tabel XIII dan Tabel XIV.

TABEL XIII. NILAI GAP DAN BOBOT PENDAHULUAN UNTUK CORE FACTOR

\begin{tabular}{|c|c|c|c|c|c|c|c|}
\hline No & Proposal ID & \multicolumn{6}{|c|}{ Core Factor } \\
\hline \multicolumn{2}{|c|}{ Nilai Proposal } & \multicolumn{2}{|c|}{$\begin{array}{c}\text { Latar } \\
\text { Belakang }\end{array}$} & \multicolumn{2}{|c|}{$\begin{array}{c}\text { Rumusan } \\
\text { Masalah }\end{array}$} & \multicolumn{2}{|c|}{$\begin{array}{c}\text { Tujuan } \\
\text { Penelitian }\end{array}$} \\
\hline 1 & PROP001 & \multicolumn{2}{|c|}{3} & \multicolumn{2}{|c|}{2} & \multicolumn{2}{|c|}{2} \\
\hline 2 & PROP002 & \multicolumn{2}{|c|}{2} & \multicolumn{2}{|c|}{3} & \multicolumn{2}{|c|}{3} \\
\hline 3 & PROP003 & \multicolumn{2}{|c|}{3} & \multicolumn{2}{|c|}{1} & \multicolumn{2}{|c|}{3} \\
\hline 4 & PROP004 & \multicolumn{2}{|c|}{2} & \multicolumn{2}{|c|}{2} & \multicolumn{2}{|c|}{3} \\
\hline 5 & PROP005 & \multicolumn{2}{|c|}{1} & \multicolumn{2}{|c|}{2} & \multicolumn{2}{|c|}{2} \\
\hline 6 & PROP006 & \multicolumn{2}{|c|}{3} & \multicolumn{2}{|c|}{2} & \multicolumn{2}{|c|}{3} \\
\hline 7 & PROP007 & \multicolumn{2}{|c|}{2} & \multicolumn{2}{|c|}{1} & \multicolumn{2}{|c|}{3} \\
\hline 8 & PROP008 & \multicolumn{2}{|c|}{3} & \multicolumn{2}{|c|}{3} & \multicolumn{2}{|c|}{2} \\
\hline \multicolumn{2}{|c|}{ Profil Ideal } & \multicolumn{2}{|c|}{3} & \multicolumn{2}{|c|}{3} & \multicolumn{2}{|c|}{3} \\
\hline \multicolumn{2}{|c|}{ Nilai } & GAP & Bobot & GAP & Bobot & GAP & Bobot \\
\hline 1 & PROP001 & 0 & 5 & -1 & 4 & -1 & 4 \\
\hline 2 & PROP002 & -1 & 4 & 0 & 5 & 0 & 5 \\
\hline 3 & PROP003 & 0 & 5 & -2 & 3 & 0 & 5 \\
\hline 4 & PROP004 & -1 & 4 & -1 & 4 & 0 & 5 \\
\hline 5 & PROP005 & -2 & 3 & -1 & 4 & -1 & 4 \\
\hline 6 & PROP006 & 0 & 5 & -1 & 4 & 0 & 5 \\
\hline 7 & PROP007 & -1 & 4 & -2 & 3 & 0 & 5 \\
\hline 8 & PROP008 & 0 & 5 & 0 & 5 & -1 & 4 \\
\hline
\end{tabular}

Sumber : Hasil Pengolahan data

TABEL XIV. NILAI GAP DAN BOBOT PENDAHULUAN UNTUK SECONDARY FACTOR

\begin{tabular}{|c|c|c|c|c|c|}
\hline No & Proposal ID & \multicolumn{4}{|c|}{ Core Factor } \\
\hline \multicolumn{2}{|c|}{ Nilai Proposal } & \multicolumn{2}{|c|}{ Manfaat Penelitian } & \multicolumn{2}{|c|}{ Luaran Penelitian } \\
\hline 1 & PROP001 & \multicolumn{2}{|c|}{3} & \multicolumn{2}{|c|}{2} \\
\hline 2 & PROP002 & \multicolumn{2}{|c|}{2} & \multicolumn{2}{|c|}{2} \\
\hline 3 & PROP003 & \multicolumn{2}{|c|}{2} & \multicolumn{2}{|c|}{1} \\
\hline 4 & PROP004 & \multicolumn{2}{|c|}{3} & \multicolumn{2}{|c|}{2} \\
\hline 5 & PROP005 & \multicolumn{2}{|c|}{1} & \multicolumn{2}{|c|}{2} \\
\hline 6 & PROP006 & \multicolumn{2}{|c|}{3} & \multicolumn{2}{|c|}{2} \\
\hline 7 & PROP007 & \multicolumn{2}{|c|}{2} & \multicolumn{2}{|c|}{1} \\
\hline 8 & PROP008 & \multicolumn{2}{|c|}{3} & \multicolumn{2}{|c|}{3} \\
\hline \multicolumn{2}{|c|}{ Profil Ideal } & \multicolumn{2}{|c|}{3} & \multicolumn{2}{|c|}{3} \\
\hline \multicolumn{2}{|c|}{ Nilai } & $\overline{G A P}$ & Bobot & GAP & Bobot \\
\hline 1 & PROP001 & 0 & 5 & -1 & 4 \\
\hline 2 & PROP002 & -1 & 4 & -1 & 4 \\
\hline 3 & PROP003 & -1 & 4 & -2 & 3 \\
\hline 4 & PROP004 & 0 & 5 & 0 & 5 \\
\hline 5 & PROP005 & -2 & 3 & 0 & 5 \\
\hline 6 & PROP006 & 0 & 5 & 0 & 5 \\
\hline 7 & PROP007 & -1 & 4 & -2 & 3 \\
\hline 8 & PROP008 & 0 & 5 & 0 & 5 \\
\hline
\end{tabular}

Penilaian terhadap subkriteria pada kriteria Pendahuluan akan memperoleh nilai profil ideal untuk masing masing 
subkriteria. Berdasarkah hasil tersebut, akan dapat ditentukan nilai GAP dan Bobot pada kriteria pendahuluan baik pada Core Factor maupun Secondary Factor dengan menggunakan persamaan 1 dan tabel 1 .

TABEL XV. NILAI GAP DAN BOBOT BT

\begin{tabular}{|c|c|c|c|}
\hline No & Proposal ID & SKOR & $\begin{array}{c}\text { Nilai } \\
\text { Proposal }\end{array}$ \\
\hline \multicolumn{3}{|c|}{ Nilai Proposal } & \\
\hline 1 & PROP001 & 3 & \\
\hline 2 & PROP002 & 2 & \\
\hline 3 & PROP003 & 3 & \\
\hline 4 & PROP004 & 1 & \\
\hline 5 & PROP005 & 2 & \\
\hline 6 & PROP006 & 3 & \\
\hline 7 & PROP007 & 3 & \\
\hline 8 & PROP008 & 2 & \\
\hline & Profil Ideal & 3 & \\
\hline \multicolumn{3}{|c|}{ Nilai GAP } & Bobot \\
\hline 1 & PROP001 & 0 & 5 \\
\hline 2 & PROP002 & -1 & 4 \\
\hline 3 & PROP003 & 0 & 5 \\
\hline 4 & PROP004 & -2 & 3 \\
\hline 5 & PROP005 & -1 & 4 \\
\hline 6 & PROP006 & 0 & 5 \\
\hline 7 & PROP007 & 0 & 5 \\
\hline 8 & PROP008 & -1 & 4 \\
\hline
\end{tabular}

Sumber : Hasil Pengolahan data

TABEL XVI. NILAI GAP DAN BOBOT BM

\begin{tabular}{|c|c|c|c|}
\hline No & Proposal ID & SKOR & $\begin{array}{c}\text { Nilai } \\
\text { Proposal }\end{array}$ \\
\hline \multicolumn{3}{|c|}{ Nilai Proposal } & \\
\hline 1 & PROP001 & 3 & \\
\hline 2 & PROP002 & 2 & \\
\hline 3 & PROP003 & 3 & \\
\hline 4 & PROP004 & 1 & \\
\hline 5 & PROP005 & 2 & \\
\hline 6 & PROP006 & 2 & \\
\hline 7 & PROP007 & 3 & \\
\hline 8 & PROP008 & 2 & \\
\hline & Profil Ideal & 3 & \\
\hline \multicolumn{3}{|c|}{ Nilai GAP } & Bobot \\
\hline 1 & PROP001 & 0 & 5 \\
\hline 2 & PROP002 & -1 & 4 \\
\hline 3 & PROP003 & 0 & 5 \\
\hline 4 & PROP004 & -2 & 3 \\
\hline 5 & PROP005 & -1 & 4 \\
\hline 6 & PROP006 & -1 & 4 \\
\hline 7 & PROP007 & 0 & 5 \\
\hline 8 & PROP008 & -1 & 4 \\
\hline
\end{tabular}

Sumber : Hasil Pengolahan data

TABEL XVII. NILAI GAP DAN BOBOT BAJ

\begin{tabular}{|c|c|c|c|}
\hline No & Proposal ID & SKOR & $\begin{array}{c}\text { Nilai } \\
\text { Proposal }\end{array}$ \\
\hline \multicolumn{3}{|c|}{ Nilai Proposal } \\
\hline 1 & PROP001 & 3 \\
\hline 2 & PROP002 & 4 \\
\hline 3 & PROP003 & 3 \\
\hline 4 & PROP004 & 1 \\
\hline 5 & PROP005 & 2 \\
\hline 6 & PROP006 & 2 & \\
\hline 7 & PROP007 & 3 & \\
\hline
\end{tabular}

\begin{tabular}{|c|c|c|c|}
\hline No & Proposal ID & SKOR & $\begin{array}{c}\text { Nilai } \\
\text { Proposal }\end{array}$ \\
\hline 8 & PROP008 & 2 & \\
\hline & rofil Ideal & 4 & \\
\hline \multicolumn{3}{|c|}{ Nilai $\mathbf{G A P}$} & Bobot \\
\hline 1 & PROP001 & -1 & 4 \\
\hline 2 & PROP002 & 0 & 5 \\
\hline 3 & PROP003 & -1 & 4 \\
\hline 4 & PROP004 & -3 & 2 \\
\hline 5 & PROP005 & -2 & 3 \\
\hline 6 & PROP006 & -2 & 3 \\
\hline 7 & PROP007 & -1 & 4 \\
\hline 8 & PROP008 & -2 & 3 \\
\hline
\end{tabular}

Sumber : Hasil Pengolahan data

Kriteria Tinjauan Pustaka, metode penelitian serta anggaran dan jadwal penelitian Nilai GAP dan Bobot diperoleh dari selisih profil proposal dan profil ideal dengan menggunakan Persamaan 1 dan tabel 1.

\section{Perhitungan Nilai Sub Kriteria.}

Perhitungan nilai sub kriteria dilakukan untuk memperoleh nilai total kriteria. Perhitungan ini hanya dilakukan pada kriteria Pendahuluan. Untuk menghitung Core factor dari sub kriteria pada pendahuluan digunakan persamaan (2) Sedangkan untuk menghitung secondary factor dari sub kriteria pendahuluan digunakan persamaan (3). Selanjutnya hasil perhitungan core factor dan secondary factor dilakukan perhitungan nilai total berdasrakan pada tabel 3 dan persamaan (4). Penggunaan Persentase pada masing masing adalah $60 \%$ untuk core factor dan $40 \%$ untuk Secondary factor. Nilai Total Kriteria Pendahuluan dapat dilihat pada tabel XVIII.

TABEL XVIII. TOTAL NILAI KRITERIA PENDAHULUAN (BP)

\begin{tabular}{|c|c|c|c|c|}
\hline No & Proposal_ID & $\boldsymbol{C F}$ & SF & BP \\
\hline 1 & PROP001 & 4,33 & 4,5 & 4,4 \\
\hline 2 & PROP002 & 4,67 & 4 & 4,4 \\
\hline 3 & PROP003 & 4,33 & 3,5 & 4 \\
\hline 4 & PROP004 & 4,33 & 5 & 4,6 \\
\hline 5 & PROP005 & 3,67 & 4 & 3,8 \\
\hline 6 & PROP006 & 4,67 & 5 & 4,8 \\
\hline 7 & PROP007 & 4 & 3,5 & 3,8 \\
\hline 8 & PROP008 & 4,67 & 5 & 4,8 \\
\hline
\end{tabular}

Sumber : Hasil Pengolahan data

\section{E. Perhitungan Perangkingan.}

Sebagai tahap akhir dari perhitungan dengan metode profile matching adalah Perangkingan untuk mengetahui nilai kelayakan proposal penelitian internal yang akan dibiayai. Untuk menentukan rangkin dari hasil penilaian yang dilakukan digunakan persamaan (5).

Nilai akhir dan perangkingan dapat dilihat pada tabel XIX. Semakin besar nilai akhir maka semakin tinggi prioritas kelulusan proposal penelitian dan sebaliknya. Pembiayaan proposal akan dilakukan sesuai dengan urutan rangking dari penilaian akhir yang dilakukan. Tabel XIX merupakan hasil perhitungan sehingga diketahui nilai akhir dan perangkingan dari proposal penelitian internal yang masuk ke LPPM. 
TABEL XIX. NILAI AKHIR DAN PERANGKINGAN

\begin{tabular}{|c|c|c|c|c|c|c|c|}
\hline Proposal_ID & BA & BP & BT & BM & BAJ & $\begin{array}{c}\text { Nilai } \\
\text { Akhir }\end{array}$ & $\begin{array}{c}\text { Rang- } \\
\text { king }\end{array}$ \\
\hline PROP001 & 3 & 4,4 & 5 & 5 & 4 & 4,4 & 3 \\
\hline PROP002 & 5 & 4,4 & 4 & 4 & 5 & 4,4 & 4 \\
\hline PROP003 & 4 & 4 & 5 & 5 & 4 & 4,45 & 2 \\
\hline PROP004 & 2 & 4,6 & 3 & 3 & 2 & 3,1 & 8 \\
\hline PROP005 & 3 & 3,8 & 4 & 4 & 3 & 3,65 & 7 \\
\hline PROP006 & 4 & 4,8 & 5 & 4 & 3 & 4,25 & 5 \\
\hline PROP007 & 5 & 3,8 & 5 & 5 & 4 & 4,55 & 1 \\
\hline PROP008 & 3 & 4,8 & 4 & 4 & 3 & 3,9 & 6 \\
\hline
\end{tabular}

Sumber : Hasil Pengolahan data

Dari data yang ada dapat diketahui bahwa Proposal dengan ID PROP007 berada diurutan rangking 1, ID PROP003 pada rangking 2, ID PROP001 pada rangking 3, PROP002 diurutan rangking 4, ID PROP006 pada rangking 5, ID PROP008 dirangking ke 6, ID PROP005 diurutan rangkin 7 dan ID PROP004 pada rangking ke 8. Berdasarkan hasil tersebut dapat diketahu bahawa nilai tertinggi adalah 4,55 yang dimiliki usulan penelitian dengan identitas ID PROP007. Sedangkan Proposal dengan ID PROP004 merupakan usulan Penelitian yang berada pada rangking terendah yaitu rangking terakhir dengan nilai akhir 3,1. Pembiayaan proposal yang dibatasi dapat dipilih dengan pengurutan rangking nilai yang diperoleh.

Implementasi dari penggunaan metode profile matching dalam menentukan penerima pembiayaan penelitian internal dosen dapat dilakukan dengan menggunakan bahasa pemrograman VB .net dengan basis data MYSQL. Sehingga dalam penggunaannya akan lebih mudah dan lebih cepat dalam penentuan penerimaan usulan penelitian internal Dosen.

\section{KESIMPULAN}

Berdasarkan hasil pengolahan data Usulan Penelitian Internal Dosen pada Perguruan Tinggi dengan Metode Profile Matching dapat diketahui hasil penelitian menunjukkan hasil bahwa dari usulan penelitian yang ada dapat ditentukan usulan proposal dengan ID PROP007 memiliki nilai akhir tertinggi yaitu 4,55 yang artinya usulan penelitian tersebut sangat layak untuk di biayai karena memenuhi kriteria yang telah ditentukan.

Pengolahan data Usulan Penelitian Internal Dosen dengan menggunakan profile matching dapat diimplementasikan dalam sebuah sistem berbasis Komputer sebagai Sistem Pendukung Keputusan untuk menentukan penerima dana Penelitian Internal dosen sehingga dapat membantu Pihak Lembaga yang membawahi kegiatan penelitian di Perguruan Tinggi untuk mengambil keputusan sesuai dengan kriteria yang telah ditentukan. Selain itu dengan menggunakan metode profile matching, dapat diketahui kekurangankekurangan yang ada pada proposal sehingga bagi penulis nantinya dapat memperbaiki kekurangan dalam hal penulisan yang ada pada proposalnya.

\section{UCAPAN TERIMA KASIH}

Terima kasih diucapkan kepada redaksi Jurnal Sisfokom yang telah meluangkan waktu dan tenaga untuk melakukan review, editing dan publishing artikel ini. Terima kasih juga kami sampaikan kepada Universitas Bina Darma yang telah membiaya penelitian ini hingga terlaksana dengan baik.

\section{DAFTAR PUSTAKA}

[1] Menteri Riset Teknologi dan Pendidikan Tinggi Republik Indonesia. Peraturan Menteri Riset, Teknologi, dan Pendidikan Tinggi Republik Indonesia Nomor 44 Tahun 2015 tentang Standar Nasional Pendidikan Tinggi (2015).

[2] Undang-Undang Republik Indonesis (UU RI) No. 14 Tahun 2005 [Online]. Available: http://www.hukum.unsrat.ac.id/uu/uu-gurudosen.htm.

[3] Undang-Undang Republik Indonesis (UU RI) No. 12 Tahun 2012 tentang Pendidikan Tinggi. [Online]. Available: http://www.sipuu.setkab.go.id/puudoc/17624/uu0122012_full.pdf.

[4] Peleyeju, J. O., \& Ojebiyi, O. A. Lecturers' performance appraisal and total quality management of Public Universities in South-Western Nigeria. British Journal of Education, vol.1 no.2, pp. 41-47. 2013. [online] available : https://www.eajournals.org/journals/british-journalof-education-bje/vol-1-issue-2-december-2013/lecturers-performanceappraisal-total-quality-management-public-universities-south-westernnigeria/

[5] Undang-Undang Republik Indonesis (UU RI) No. 20 Tahun 2003 tentang sistem Pendidikan Nasional. [Online]. Available: http://www.kelembagaan.ristekdikti.go.id/wpcontent/upload/2016/08/uu_no_20_th_2003.pdf

[6] Hemmings, B., \& Kay, R. Lecturer self efficacy, research skills, and publication output. Sydney: Charles Sturt University. 2014.

[7] Retnowati, T. H., Mardapi, D., Kartowagiran, B., \& Suranto, S. Model evaluasi kinerja dosen: pengembangan instrumen untuk mengevaluasi kinerja dosen. Jurnal Penelitian Dan Evaluasi Pendidikan, vol. 21 no.2, 206. 2017. https://doi.org/10.21831/pep.v21i2. 16626

[8] Rohmah, N., Huda, M., \& Kusmintardjo, K.. Strategi peningkatan kemampuan dosen dalam penulisan karya ilmiah (studi multi kasus pada Unisda dan Staidra di Kabupaten Lamongan). Jurnal Pendidikan: Teori, Penelitian, Dan Pengembangan, vol. 1 no.7. 2016. https://dx.doi.org/10.17977/jp.v1i7.6560

[9] Kusrini. Konsep dan Aplikasi Sistem Pendukung Keputusan. Peneribut: Andi. Yogyakarta. 2007.

[10] Sugiyono. Metode Penelitian Kuantitatif, Kualitatif, dan R\&D. Bandung: Alfabeta. 2017

[11] Mulyadi, Moh. Metode Penelitian Praktis Kualitatif dan Kuantitatif. Jakarta: Publikas Press. 2016

[12] Arikunto, S. Prosedur Penelitian Suatu Pendekatan Praktik. Jakarta: Rineka Citra.2016

[13] Khairullah, Risqi Albi., dkk. Sistem Pendukung Keputusan Sistem Penerimaan Pegawai Baru Menggunakan Profile Matching (Studi Kasus: Kecamatan Silo. 2016. [online] Available: http://digilib.unmuhjember.ac.id/files/disk1/37/umj-1x-risqialbik-18161-artikel-i.pdf

[14] Sari, Bety Wulan. Perbandingan Metode Profile Matching dan Simple Additive Weigthing pada Penentuan Jurusan Siswa Kelas X SMAN 2 Ngaglik. Jurnal Ilmiah DASI, Vol.16 no. 1, pp. 16-22, maret, 2015.

[15] Junaidi, Agus \& Visella , Fany., Pemilihan Penerima Beasiswa Menggunakan Metode Profile Matching. Jurnal Paradigma, Vol. 19 No.2, pp.118-126, September, 2017. https://doi.org/10.31294/p.v19i2.2227

[16] Apriani, Veti. Penerapan Profile Matching untuk Menentukan Pemberian Beasiswa pada Sekolah Menengah Atas. Jurnal Mantik Penusa, Vol.3 No.1, pp.15-21, juni, 2019.

[17] Frieyadie. Penggunaan Metode Profile Matching Untuk Sistem Penunjang Keputusan Kenaikan Jabatan pada Instansi Pemerintah. Jurnal Paradigma, Vol.18 No.2, pp.75-80, September, 2016. https://doi.org/10.31294/p.v181i2.1228 